\title{
Wound Healing Activity of Crassocephalum crepidioides (Benth.) S. Moore. Leaf Hydroethanolic Extract
}

\author{
Nguyen Minh Can ${ }^{1,2,3}$ and Dang Thi Phuong Thao $\mathbb{D}^{1,2}$ \\ ${ }^{1}$ Faculty of Biology-Biotechnology, University of Science, Ho Chi Minh City, Vietnam \\ ${ }^{2}$ Vietnam National University in Ho Chi Minh City, Vietnam \\ ${ }^{3}$ Department of Biology and Agricultural Engineering, Pham Van Dong University, Quang Ngai, Vietnam \\ Correspondence should be addressed to Dang Thi Phuong Thao; thaodp@hcmus.edu.vn
}

Received 7 April 2020; Revised 31 May 2020; Accepted 11 June 2020; Published 25 August 2020

Guest Editor: German Gil

Copyright (C) 2020 Nguyen Minh Can and Dang Thi Phuong Thao. This is an open access article distributed under the Creative Commons Attribution License, which permits unrestricted use, distribution, and reproduction in any medium, provided the original work is properly cited.

\begin{abstract}
Crassocephalum crepidioides (Benth.) S. Moore. has been used to treat small wounds by minority people in Lam Dong, Vietnam. However, there has been no scientific evidences about its wound healing activity. This study is aimed at evaluating the wound healing activity of Crassocephalum crepidioides hydroethanolic extract via its antioxidant and anti-inflammation activities and healing capability on a mouse excision wound model. Crassocephalum crepidioides hydroethanolic extract (CCLE) at a dose of $50 \mathrm{mg} / \mathrm{kg} /$ day reduced the wound closure time about 3.5 days, compared to vehicle treatment. The granulation tissue on day 7 after surgery from the treated group showed a 2.8 -fold decrease in the density of inflammatory cells, 1.9 -fold increase in the fibroblast density, and a higher number of blood vessels. Real-time PCR analysis indicated that the mRNA expression level of NF- $\kappa$ B1 and TNF- $\alpha$ mRNA in CCLE-treated wounds decreased by 4.6 and 3.3 times, respectively, while TGF- $\beta 1$ and VEGF were found to increase by 3.3 and 2.4 times, respectively. Our experimental data provided proofs of Crassocephalum crepidioides leaf wound healing activity due to its antioxidant, anti-inflammation, fibroblast proliferation, wound contraction, and angiogenesis effects.
\end{abstract}

\section{Introduction}

Wound healing is a complex process that often is divided into 3 overlap phases: inflammation, proliferation, and remodeling $[1,2]$. The inflammatory phase starts immediately after injury, together with hemostasis. In this phase, leukocytes are recruited to the wound site to remove alien substances and dead tissue and prevent infection [1,2]. Fibroblasts and keratinocyte proliferation and migration play a key role in the proliferation phase. Fibroblasts are predominant cells at the wound site in this phase, responsible for new matrix and collagen production [2]. The remodeling phase occurs in several months to years, involving change in components of the extracellular matrix at the wound site and restoration of about $80 \%$ of tensile strength normal skin [2].

Many traditional medicinal plants (TMPs) have been discovered and used for wound care for centuries. Recent reports suggested that the wound healing mechanism of
TMPs might be due to antioxidant, antimicrobial, and antiinflammatory activities and stimulation on DNA and protein synthesis, epithelium cell proliferation, collagen formation, and angiogenesis $[3,4]$.

Crassocephalum crepidioides (Benth.) S. Moore. (Compositae family) is a TMP found in various parts of Asia, Africa, and Australia [5]. The leaves of C. crepidioides are traditionally used to treat indigestion, stomachache [5-7], and wound $[8,9]$. C. crepidioides has been reported to have antibacterial [10], hypoglycemic, antioxidant [11, 12], anti-inflammatory $[13,14]$, antitumor [14], and antidiabetic $[12,15]$ activities. Several bioactive compounds have been found in C. crepidioides leaves, including some phenolic and flavonoid compounds $[11,16]$; the essential oil from $C$. crepidioides leaves contains $\beta$-cubebene, $\alpha$-farnesene, and $\alpha$-caryophyllene. $C$. crepidioides leaves has been also used for treating wounds in Vietnam, China, India, and some African countries $[8,9$, 17]. However, there have been no published materials 
proving C. crepidioides wound healing activity. This study is aimed at investigating the wound healing activity of C. crepidioides hydroethanolic leaf extract (CCLE) on a mouse excision wound model, focusing on the wound closure rate, histopathology characteristics, and the mRNA expression level of several genes involved in the wound healing process.

\section{Materials and Methods}

2.1. Plant Samples and Preparation of Extract and Fractions. C. crepidioides (voucher specimen number PHH0004878) were collected from Bidoup Nui Ba National Park, Lam Dong, Vietnam. The sample was washed by clean water and dried in an oven at $40^{\circ} \mathrm{C}$. The dried sample was homogenized to fine powder for further extraction. The dried powder was soaked in ethanol $70 \%$ for $48 \mathrm{~h}(w / v=1: 10)[18,19]$. The solvent is preferred for preparing the extract for bioactivity evaluation purposes because of its low toxicity to cells and animals. The liquid phase then was filtered and dried by a rotary vacuum evaporator until constant weight to obtaine CCLE. The extract was kept at $-20^{\circ} \mathrm{C}$ for later experiments.

2.2. Total Phenolic Content. Total phenolic content (TPC) in CCLE was evaluated using a Folin-Ciocalteu colorimetric assay described by Do et al., with slight modification [20]. The sample was dissolved in $70 \%$ ethanol solution; $80 \mu \mathrm{L}$ of the sample was added to $800 \mu \mathrm{L}$ Folin-Ciocalteu solution (10-fold diluted) in a glass tube, then added $800 \mu \mathrm{L} \mathrm{Na} \mathrm{CO}_{3}$ (7.5\%) and $320 \mu \mathrm{L}$ distilled water, mixed thoroughly, and left standing for 30 minutes at room temperature in dark condition. The absorbance of the mixture was measured at $760 \mathrm{~nm}$ using a UV-VIS spectrophotometer V-7200 model (Jasco, Tokyo, Japan). TPC was expressed as milligram gallic acid equivalent per gram of CCLE (mg GAE/gE).

2.3. Total Flavonoid Content. The total flavonoid content (TFC) CCLE was evaluated according to the method described by Msaada et al. with minor modifications [21]. The CCLE sample was diluted with ethanol $70 \%$ solution; $200 \mu \mathrm{L}$ sample was added to a glass tube containing $120 \mu \mathrm{L}$ of $\mathrm{NaNO}_{2} 5 \%$; the mixture was vortexed for 10 seconds and left standing for 5 minutes. Then, $120 \mu \mathrm{L}$ of $\mathrm{AlCl}_{3}(10 \%)$ and $800 \mu \mathrm{L}$ of $\mathrm{NaOH} 1 \mathrm{M}$ were added to the tube. The mixture was then adjusted to $2 \mathrm{~mL}$ with distilled water and vortexed for 10 seconds, and absorbance was measured at $415 \mathrm{~nm}$. TFC was expressed as milligram quercetin equivalent per gram of CCLE (mg QE/gE).

2.4. DPPH Free Radical-Scavenging Activity. Antioxidant activity of CCLE was investigated by 2,2-diphenyl-1-picrylhydrazyl (DPPH) free radical-scavenging capacity. DPPH $100 \mu \mathrm{M}$ solution and CCLE were prepared in ethanol 70\%; $2 \mathrm{~mL}$ of DPPH solution was mixed with $0.5 \mu \mathrm{L}$ samples at a concentration of $200,100,50,25$, and $12.5 \mu \mathrm{g} / \mathrm{mL}$ in a glass tube. The mixture was vortexed and then incubated for 30 minutes in the dark at room temperature. The mixture of $0.5 \mu \mathrm{L}$ ethanol $70 \%$ with $2 \mathrm{~mL}$ DPPH $100 \mu \mathrm{M}$ was used as blank. Absorbance at wavelength $517 \mathrm{~nm}$ was measured by spectrophotometer UV-Vis V730. Gallic acid solutions at a concentration of $50,40,30,20$, and $10 \mu \mathrm{g} / \mathrm{mL}$ were used as the positive control. The scavenging capacity of CCLE is calculated by the following formula:

$$
\text { Scavenging capacity }=\frac{\mathrm{Ao}-\mathrm{Aj}}{\mathrm{Ao}} \times 100(\%),
$$

where Ao was the absorbance of blank and $\mathrm{Aj}$ was the absorbance of the sample.

The $\mathrm{IC}_{50}$ value was estimated using GraphPad Prism 7.04 .

2.5. Cell Culture. Murine macrophage cells RAW 264.7 (ATCC ${ }^{\circledR}$ TIB-71 ${ }^{\mathrm{TM}}$ ) were cultured in DMEM-F12 medium supplemented with penicillin and streptomycin (Sigma) and $10 \%$ heat-inactivated FBS in 96 -well plates, at $37^{\circ} \mathrm{C}$ and under an atmosphere of $5 \% \mathrm{CO}_{2}$. The cells were seeded at a density of $10^{4}$ cells/well with $100 \mu \mathrm{L}$ medium and subculture every 3 days.

2.6. Cell Viability. Toxicity of CCLE on cell RAW 264.7 viability was estimated by a 3-(4,5-dimethylthiazol-2-yl)-2,5diphenyltetrazolium bromide (MTT) assay. Briefly, cells were seeded with $100 \mu \mathrm{L}$ DMEM-F12 medium supplemented with penicillin and streptomycin (Sigma) and 10\% heatinactivated FBS in 96-well plates at a density of $10^{4}$ cells/well. After 24 hours, the medium was removed and replaced with fresh medium supplemented with LPS $1 \mu \mathrm{g} / \mathrm{mL}$; CCLE was dissolved in DMSO $10 \%$ in the range of 2 times dilution concentration (from $1000 \mu \mathrm{g} / \mathrm{mL}$ to $15.625 \mu \mathrm{g} / \mathrm{mL}$ ) and added to the medium (final concentration of DMSO was $0.1 \%$ ). After 48 hours of incubation, $10 \mu \mathrm{L}$ MTT was added to each well, followed by incubation for 3 hours; then, the supernatant was removed and formazan was dissolved with $100 \mu \mathrm{L}$ isopropanol- $\mathrm{HCl}$; the measured optical density at wavelength is $550 \mathrm{~nm}$. Cell viability was calculated by the following formula:

$$
\text { Cell viability }(\%)=\frac{\mathrm{OD}_{\text {sample }}}{\mathrm{OD}_{\text {control (without LPS) }}} \times 100 \text {. }
$$

2.7. Anti-inflammation Activity. Anti-inflammation activity was investigated via the amount of nitric oxide (NO) production in the murine macrophage cell RAW 264.7 (ATCC ${ }^{\circledR}$ TIB- $71^{\mathrm{TM}}$ ) induced with lipopolysaccharide (LPS) by the method of $\mathrm{Heo}$ et al. [22] with modification. Cells were seeded with $100 \mu \mathrm{L}$ DMEM-F12 medium supplemented with penicillin and streptomycin (Sigma) and 10\% heatinactivated FBS in 96-well plates at a density of $10^{4}$ cells/well. After 24 hours, the medium was replaced with fresh medium supplemented with LPS $1 \mu \mathrm{g} / \mathrm{mL}$ with or without CCLE (CCLE was prepared in DMSO 10\% and supplemented to medium at a final concentration of $125,62.5$, and $31.25 \mu \mathrm{g} / \mathrm{mL}$ ), incubated for 48 hours. Then, $50 \mu \mathrm{L}$ of cell culture supernatant was mixed with $50 \mu \mathrm{L}$ of the Griess reagent and incubated at room temperature in darkness for 10 minutes. Absorbance at $550 \mathrm{~nm}$ was measured using an ELISA reader. 
TABle 1: Primers used for RT-PCR.

\begin{tabular}{lc}
\hline Gene & Primers (forward/reverse) \\
\hline GAPDH & $5^{\prime}$-AATGTGTCCGTCGTGGATCTGA-3' \\
& $5^{\prime}$-AGTGTAGCCCAAGATGCCCTTC-3' \\
TNF- $\alpha$ & $5^{\prime}$-CGAGTGACAAGCCTGTAGCC-3' \\
& $5^{\prime}$-GTGGGTGAGGAGCACGTAGT-3' \\
NF- $\kappa$ B1 & $5^{\prime}$-CTGACCTGAGCCTTCTGGAC-3' \\
& $5^{\prime}$-GCAGGCTATTGCTCATCACA-3' \\
TGF- $\beta 1$ & $5^{\prime}$-CGCAACAACGCAATCTATG-3' \\
& $5^{\prime}$-ACCAAGGTAACGCCAGGA-3' \\
VEGF & $5^{\prime}$-TCACCAAAGCCAGCACATAGGAGA-3' \\
& $5^{\prime}$-TTACACGTCTGCGGATCTTGGACA-3'
\end{tabular}

TABle 2: Phenolic content, flavonoid content, and DPPH scavenging capacity of CCLE.

\begin{tabular}{lccc}
\hline & $\begin{array}{c}\text { TPC } \\
(\mathrm{mg} \text { GAE/g CCLE) }\end{array}$ & $\begin{array}{c}\text { TFC } \\
(\mathrm{mg} \text { QE/g } \\
\text { CCLE })\end{array}$ & $\begin{array}{c}\text { DPPH scavenging } \\
\text { capacity- }-\mathrm{IC}_{50} \\
(\mu \mathrm{g} / \mathrm{mL})\end{array}$ \\
\hline $\begin{array}{l}\text { CCLE } \\
\begin{array}{l}\text { Gallic } \\
\text { acid }\end{array}\end{array}$ & $114.3 \pm 1.7$ & $145.4 \pm 3.1$ & $48.0 \pm 1.0$ \\
\hline
\end{tabular}

Data are presented as the mean \pm SEM.

2.8. Wound Healing Activity Evaluation. Male Albino Swiss mice (Mus musculus) were purchased from Ho Chi Minh City Pasteur Institute, Vietnam. Mice were kept in laboratory conditions for a week $\left(25^{\circ} \mathrm{C}\right.$, with 12 hours of light-dark cycle) and have free access to water and food during the experiment process. The mice (weighing $25 \pm 2$ ) were anaesthetized with ketamine (Troy Laboratories) $80 \mathrm{mg} / \mathrm{kg}$ and xylazine (Troy Laboratories) $10 \mathrm{mg} / \mathrm{kg}$. To create a wound, the dorsal surface was shaved and then cleaned with ethanol $70 \%$. The excision wound ( $12 \mathrm{~mm}$ : diameter) was made with a biopsy punch (Medax). The mice were divided into 3 groups $(n=6)$. Each mouse was topically treated everyday with $25 \mu \mathrm{L}$ of CCLE $50 \mathrm{mg} / \mathrm{mL}$ and $10 \mathrm{mg} / \mathrm{mL}$, dissolved in DMSO 5\%, Tween $205 \%$ mixture, which is, respectively, equivalent to $50 \mathrm{mg} / \mathrm{kg} / \mathrm{day}(\mathrm{mg} / \mathrm{kg} / \mathrm{d})$ and $10 \mathrm{mg} / \mathrm{kg} / \mathrm{d}$ of CCLE. In the control group, each mouse was treated with $25 \mu \mathrm{L} \mathrm{DMSO} \mathrm{5 \%} \mathrm{and} \mathrm{Tween} 205 \%$ mixture in the same way. Photos were taken on the days 4,8 , and 12 after surgery. The wound area was measured by ImageJ $1.50 \mathrm{~b}$ software. The wound closure rate was calculated by the following formula [23]:

Wound closure $($ day $n)(\%)=\frac{\text { wound area at day } 0 \text {-wound area at day } n}{\text { wound area at day } 0} \times 100$.

2.9. Histological Evaluation of the Wounds. After 7 days, the granulation tissues from the 7-day wounds were taken and fixed in formalin solution (10\% formalin in phosphatebuffered saline) overnight. The tissue then was dehydrated, cleared, embedded in paraffin by a tissue processing machine, and stained with haematoxylin-eosin (HE). The staining images were taken by a light microscope (BX53, Olympus). Images were analyzed for inflammatory cells, fibroblasts, and blood vessel density using the software ImageJ $1.50 \mathrm{~b}$.

2.10. RNA Extraction and Quantitative Real-Time PCR. After 7 -day treatment, granulation tissues $(30 \mathrm{mg})$ from wounds were collected for RNA extraction, using a TRIzol reagent (Invitrogen). RT-qPCR was used for evaluating mRNA expression of some genes involved in the wound healing process, including tumor necrosis factor $\alpha$ (TNF- $\alpha$ ), nuclear factor kappa-light-chain-enhancer of activated B cells 1 (NF$\kappa \mathrm{B} 1$ ), transforming growth factor 1 (TGF- $\beta 1$ ), and vascular endothelial growth factor (VEGF). The glyceraldehyde 3phosphate dehydrogenase (GAPDH) gene was the housekeeping genes. The primers used for the genes are listed in Table 1.

The reverse transcription reactions were performed with $1 \mu \mathrm{g}$ total RNA on a total volume of $20 \mathrm{~mL}$ using a PrimeScript RT reagent kit (Takara, Japan). The Applied Biosystems 7500 real-time PCR system was used for carrying out and analyzing real-time PCR. Briefly, the reactions were performed in a $20 \mathrm{~mL}$ volume using a SYBR Green reaction mix (Takara, Japan) with $2 \mu \mathrm{L}$ cDNA. The conditions for amplification reaction were $30 \mathrm{~s}$ at $95^{\circ} \mathrm{C}, 40 \mathrm{cycles}$ of $30 \mathrm{~s}$ at $95^{\circ} \mathrm{C}$, and $30 \mathrm{~s}$ at $60^{\circ} \mathrm{C}$. Gene expression in the treatment group was compared with the control group via the fold change in mRNA expression, which was calculated by the following formula [24]:

$$
\text { Fold change }=2^{-\left(\Delta \mathrm{CT} \_ \text {sample}-\Delta \mathrm{CT} \_ \text {control }\right)},
$$

where

$$
\begin{aligned}
\Delta \mathrm{CT} \_ \text {sample }= & \mathrm{CT}_{(\text {target gene of CCLE-treated group })} \\
& -\mathrm{CT}_{(\mathrm{GAPDH} \text { of CCLE-treated group })}, \\
\Delta \mathrm{CT} \_ \text {control }= & \mathrm{CT}_{(\text {target gene of control group })} \\
& -\mathrm{CT}_{(\text {GAPDH of control group })} .
\end{aligned}
$$

CT is threshold cycle values.

2.11. Statistical Analysis. GraphPad Prism 7.04 software was used for analyzing statistical differences (by ANOVA method with Tukey test) and calculating column statistics.

\section{Results}

3.1. Total Phenolic Content, Flavonoid Contents, and Antioxidant Activity of CCLE. The hydroethanolic extract from $C$. crepidioides leaves was obtained with a yield about $16.75 \%$ of dried weight. Total phenolic content (TPC) was estimated using a Folin-Ciocalteu colorimetric assay. The TPC of CCLE was $114.3 \pm 1.7 \mathrm{mg} \mathrm{GAE} / \mathrm{g}$ CCLE. The total flavonoid content (TFC) of CCLE was $145.46 \pm 3.1 \mathrm{mg} \mathrm{QE} / \mathrm{g}$ CCLE, using the aluminum chloride colorimetric method (Table 2). Antioxidant activity of CCLE was investigated by 
TABLE 3: Effect of CCLE on the wound closure rate and reepithelialization time.

\begin{tabular}{|c|c|c|c|c|}
\hline \multirow{2}{*}{ Groups } & \multicolumn{3}{|c|}{ Wound closure percentage (\%) at days postwounding } & \multirow{2}{*}{ RE time (days) } \\
\hline & 4 & 8 & 12 & \\
\hline Control & $15.4 \pm 4.9$ & $46.5 \pm 7.7$ & $80.3 \pm 7.9$ & $19.7 \pm 2.4$ \\
\hline CCLE $10 \mathrm{mg} / \mathrm{kg} / \mathrm{d}$ & $21.5 \pm 6.0$ & $49 \pm 18.7$ & $89.1 \pm 20.9$ & $16.8 \pm 1.5$ \\
\hline CCLE $50 \mathrm{mg} / \mathrm{kg} / \mathrm{d}$ & $28 \pm 12.0^{*}$ & $51.4 \pm 13.0$ & $92.1 \pm 9.5$ & $16.2 \pm 1.9^{*}$ \\
\hline
\end{tabular}

RE: reepithelialization time. Data are presented as the mean $\pm \mathrm{SD}, n=6$. ${ }^{*}$ Significant difference, compared to the control (DMSO 5\%+Tween $205 \%$ ), $p<0.05$, using unpaired $t$-test.

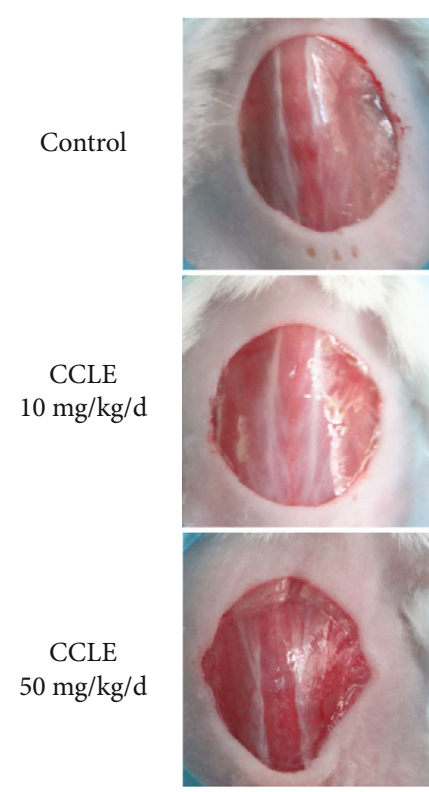

Day 0

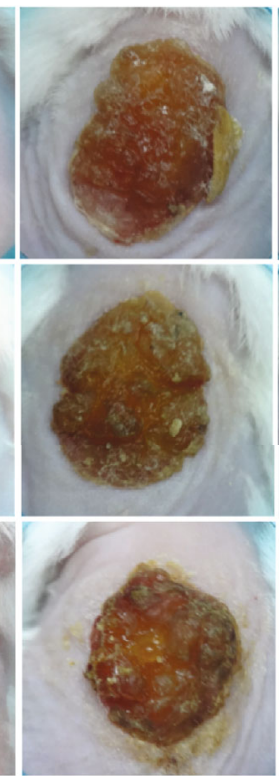

Day 4

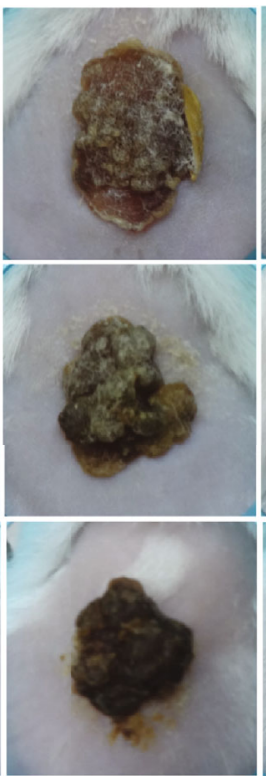

Day 8

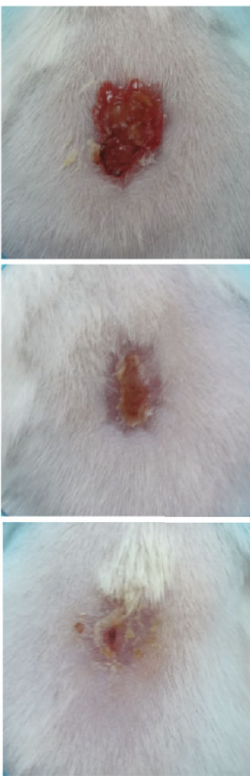

Day 12

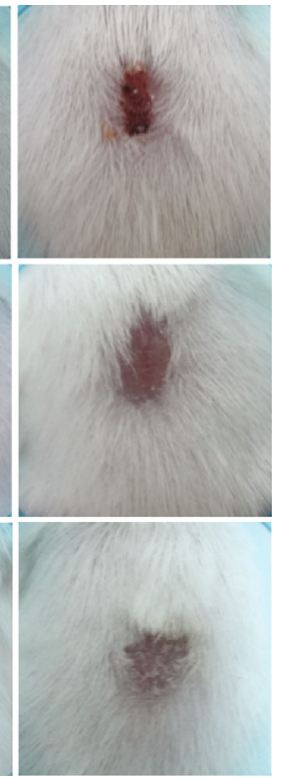

Day 16

FIGURE 1: Effect of CCLE on the wound healing process in mice.

DPPH free radical-scavenging capacity and showed its $\mathrm{IC}_{50}$ as $48.0 \mu \mathrm{g} / \mathrm{mL}$ (Table 2).

\subsection{CCLE Showed Wound Healing Activity in Mouse Model.} Significant differences in the wound closure rate and reepithelialization between CCLE treatment groups and the control group indicated that CCLE have wound healing activity in the mouse model. The results in Table 3 and Figures 1 and 2 showed that CCLE topical treatment dosedependently increased the wound closure rate. The wound closure percentage in the CCLE $50 \mathrm{mg} / \mathrm{kg} / \mathrm{d}$-treated group was significantly higher than that in the control group at an early stage, which was $28.0 \%$, while the percentage in the control group was $15.4 \%$ after 4 days. Consequently, CCLE reduced the complete reepithelialization time significantly, which was approximately 3.5 days faster.

In the wound healing process, the inflammatory phase happens immediately after injury and reduces gradually; the proliferation phase starts at late of the inflammatory phase, together with an increase of fibroblasts [25]. In our study, histopathological analysis of the 7-day-old wounds in the CCLE-treated groups showed a decrease in the inflammatory cell density, along with an increase in the fibroblast density and the blood vessel number, compared to that of the control group. Besides, better reepithelialization was also observed in the CCLE-treated wounds (Figure 2). Figures 2(b) and 2(c) showed better epidermis layer formation in CCLE-treated wounds at a dose of $10 \mathrm{mg} / \mathrm{kg} / \mathrm{d}$ and $50 \mathrm{mg} / \mathrm{kg} / \mathrm{d}$, respectively, compared to that of the control (Figure 2(a)). Figures 2(e) and 2(f) indicated that CCLE-treated wounds had less inflammatory cells and more fibroblasts and blood vessels than the nontreatment wounds (Figure 2(d)).

3.3. CCLE Anti-inflammatory Activity. After the toxicity of CCLE on RAW 264.7 cells was tested, the CCLE concentrations which showed no toxicity to the cells $(125,62.5$, and $31.25 \mu \mathrm{g} / \mathrm{mL}$ ) were used for anti-inflammatory analysis (Figure 3). CCLE showed anti-inflammatory capacity in vitro via the decrease of NO production in the mouse macrophage cell RAW 264.7 induced with LPS $0.1 \mu \mathrm{g} / \mathrm{mL}$ (Figure 4(a)). Anti-inflammation effect of CCLE was dose-dependent, with the highest inhibition of NO production at $91.4 \%$ when cells were treated with CCLE at a concentration of $125 \mu \mathrm{g} / \mathrm{mL}$.

Analysis from the histopathology result of 7-day-old wounds indicated that CCLE treatment at a dose of 


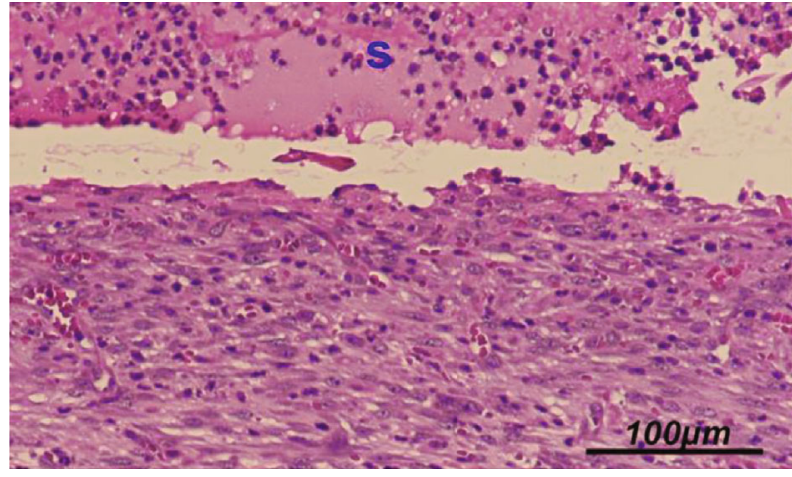

(a)

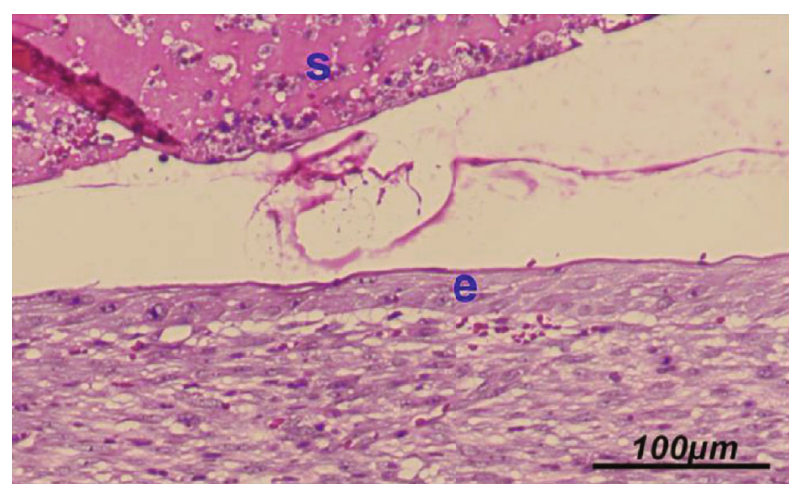

(c)

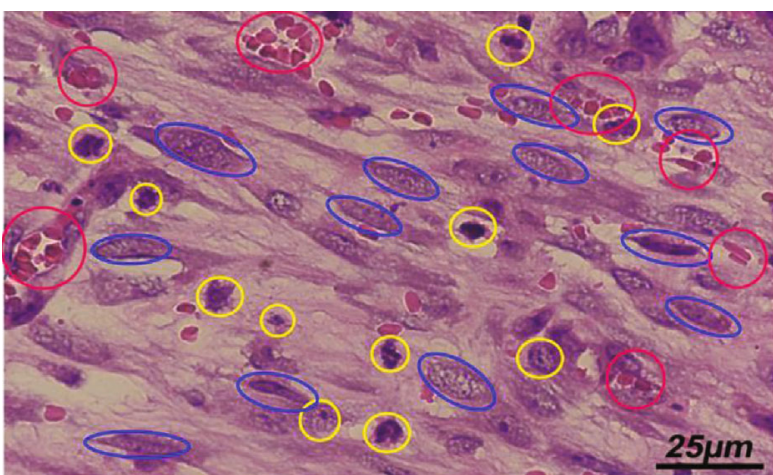

(e)

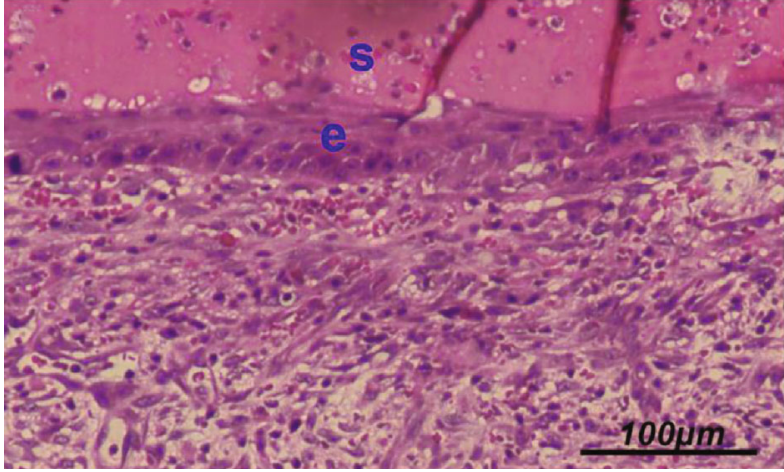

(b)

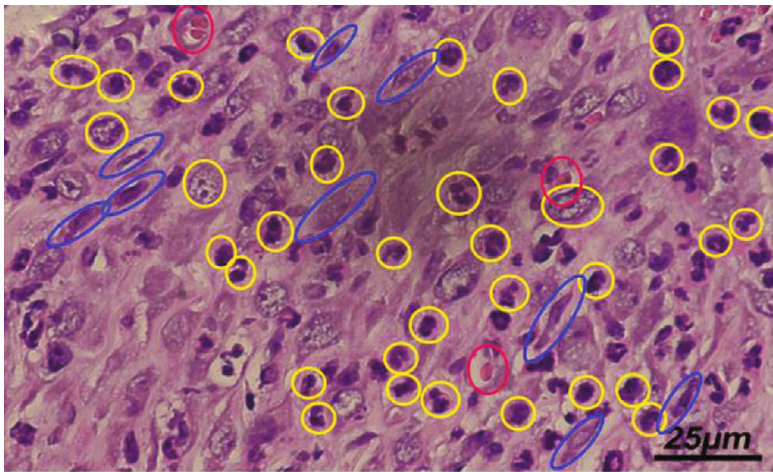

(d)

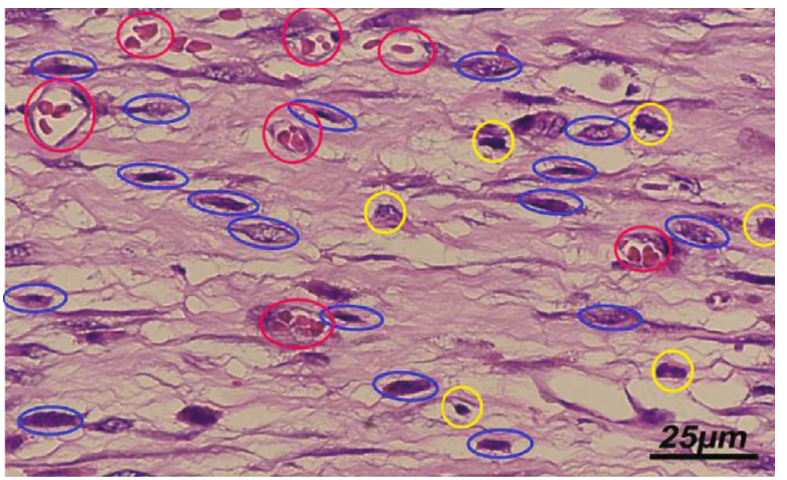

(f)

FIGURE 2: HE staining images of cross-sections of granulation tissues obtained at 7 days postwounding. (a, d) Vehicle-treated group; (b, e) CCLE $10 \mathrm{mg} / \mathrm{kg} / \mathrm{d}$-treated group; (c, f) CCLE $50 \mathrm{mg} / \mathrm{kg} / \mathrm{d}$-treated group. s: scab; e: epidermis; blue ellipses: fibroblasts; yellow ellipses: inflammatory cells; red ellipses: blood vessels.

$50 \mathrm{mg} / \mathrm{kg} / \mathrm{d}$ reduced the inflammatory cell density by 2.8 times (Figure 4(a)). In addition, CCLE treatment decreased the mRNA expression of TNF- $\alpha$ and NF- $\kappa$ B1 dosedependently. Wounds treated with CCLE $10 \mathrm{mg} / \mathrm{kg} / \mathrm{d}$ and $50 \mathrm{mg} / \mathrm{kg} / \mathrm{d}$ had levels of TNF- $\alpha$ mRNA lower than the control 2.1 and 3.3 times, respectively (Figure 4(b)). The mRNA expression level of NF- $\kappa \mathrm{B} 1$ in the $10 \mathrm{mg} / \mathrm{kg} / \mathrm{d}$ and $50 \mathrm{mg} / \mathrm{kg} / \mathrm{d}$ CCLE-treated groups was also downregulated by 3.3 and 4.6 times, respectively, compared to that of the control (Figure 4(c)). Combined with the NO production inhibition in RAW 264.7 cells, the decrease of inflammatory cell density in granulation tissue and the mRNA downregulation of TNF- $\alpha$ and NF- $\kappa$ B1 genes suggested that CCLE has antiinflammatory activity.
3.4. CCLE Treatment Increases Fibroblast Density and TGF$\beta 1$ mRNA Expression. Fibroblast proliferation is essential to the wound healing process. The HE staining images of 7day-old wound granulation revealed a significant increase of the fibroblast cell density by 1.9 times in the $50 \mathrm{mg} / \mathrm{kg} / \mathrm{d}$ CCLE-treated group, compared to that of the control group (Figure 5(a)). Besides, the two CCLE treatment groups also increased TGF- $\beta 1$ gene expression by 2.2 and 3.3 times, respectively, to $10 \mathrm{mg} / \mathrm{kg} / \mathrm{d}$ and $50 \mathrm{mg} / \mathrm{kg} / \mathrm{d}$ doses of CCLE (Figure 5(b)). TGF- $\beta 1$ has been reported to be involved in induction on fibroblast proliferation [26-28]. Therefore, the increase of TGF- $\beta 1$ gene expression is strongly correlated with the increase of the fibroblast number in the HE staining images. 


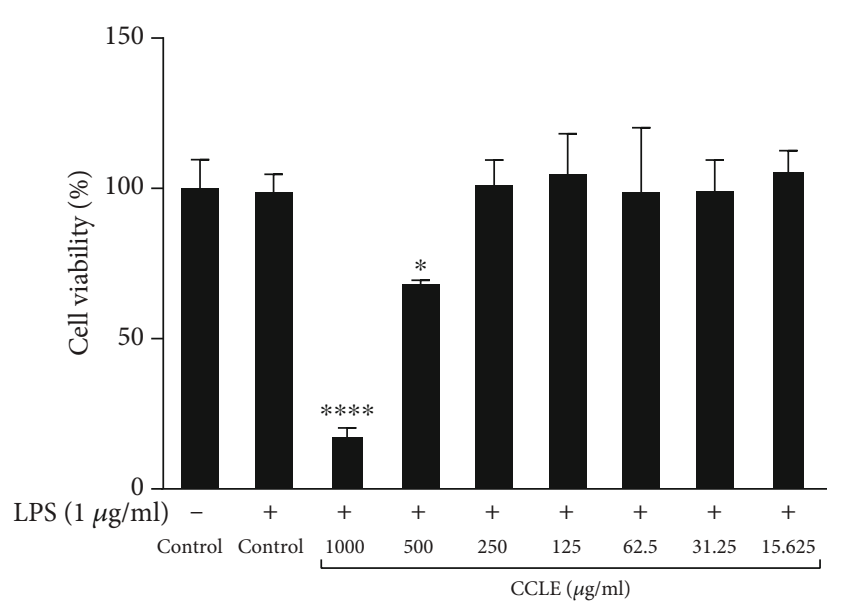

Figure 3: Effect of CCLE on RAW 264.7 cell viability. Vertical columns and bars show data as the mean \pm SD.

3.5. CCLE Stimulated Angiogenesis. The results in Figure 6 indicated that CCLE has angiogenesis stimulation activity. Wounds from CCLE treatment mice have better neovascularization (Figures 2(e) and 2(f)), compared to the control group (Figure $2(\mathrm{~d})$ ). In addition, in the CCLE-treated group at the dose of $50 \mathrm{mg} / \mathrm{kg} / \mathrm{d}$, VEGF mRNA expression also significantly increased by 2.4 times, compared to the control (Figure 4).

\section{Discussion}

C. crepidioides are traditionally used to treat indigestion, stomachache [5-7], and wound [8,9]. In this study, we have proven that $C$. crepidioides leaves have wound healing activities.

CCLE showed anti-inflammation in an in vitro assay on macrophage cell line RAW 246.7 induced with LPS. It also reduced the density of inflammatory cells in granulation tissues in 7-day-old wounds, combined with a reduced mRNA expression level of TNF- $\alpha$ and NF- $\kappa \mathrm{B} 1$. NF- $\kappa \mathrm{B} 1$ and TNF- $\alpha$ are important markers for the inflammation level [24]. TNF- $\alpha$ is an important proinflammatory cytokine. NF- $\kappa \mathrm{B} 1$ was also reported to be in a direct ratio to the inflammatory level in previous studies $[25,29]$. A high level of TNF- $\alpha$ has been reported to inhibit the wound reepithelialization and the formation of myofibroblast and $\alpha$-smooth muscle actin $(\alpha$-SMA) $[28,30]$. Overinflammation may lead to a delay or failure to heal and may turn into a chronic wound [28]. The decrease in the inflammatory level at the middle and late stages, as well as the decrease of the inflammatory markers, including TNF- $\alpha$ and NF- $\kappa \mathrm{B} 1$, has been widely considered as a good signal of the healing process $[24,31]$. Our results suggested that CCLE might improve the wound healing process via its anti-inflammatory activity. Akinpelu et al. (2019) have proven that water extracts of $C$. crepidioides leaves had anti-inflammation activity via red blood cell membrane stabilization [13]. Bello et al. [32] also found that methanolic extract of $C$. crepidioides had anti-inflammatory activity by lipoxygenase inhibition.
In addition, CCLE treatment increased the fibroblast density at wound sites. TGF- $\beta 1$ mRNA also was found to increase in granulation tissue of the CCLE-treated group. TGF- $\beta 1$ is involved in many important effects on the wound healing process $[30,33]$. The activities of TGF- $\beta 1$ include fibroblast proliferation induction $[26,34]$, motivating fibroblast differentiation into myofibroblast [27], and enhancement of collagen synthesis, deposition, and maturation [35]. Some wound healing agents have been reported to induce TGF- $\beta 1$ expression along with fibroblast proliferation in an animal model $[36,37]$. The increase of the TGF- $\beta 1$ gene may explain the increase of fibroblasts and the wound healing effect of CCLE.

Our data indicated that CCLE treatment increased neovascularization in the wounds 7 days after surgery. Moreover, CCLE treatment also increased the VEGF mRNA expression at wound sites. An increase in angiogenesis supports the wound healing process, and delayed or inhibition in angiogenesis impairs wound healing [38, 39]. VEGF is a principal mediator of wound angiogenesis [40]. It has functions not only to promote angiogenesis at several stages during the healing process but also to maintain vessel integrity. VEGF also stimulates the endothelial cell proliferation and increases vascular permeability [39]. The angiogenesis stimulation has been reported in several wound healing remedies and plants; some of them have been reported to induce the expression of VEGF [31, 36 , 37]. Since VEGF plays an important role in stimulation of angiogenesis [39], these results may suggest an explanation for angiogenesis stimulation activity of CCLE during the wound healing process.

In addition, a high level of free radical causes oxidative stress to cells, leading to damage of biological material such as protein, DNA, lipid, and tissues [41, 42]. Many wound healing agents showed antioxidant activity [43, 44]. In our study, CCLE showed antioxidant activity via its scavenging capacity to DPPH free radicals. C. crepidioides leaf extracts have been also found to showed antioxidant activity in DPPH, 2,2' -azino-bis-(3-ethyl)benzothiazoline-6-sulfonic acid, ferric reducing antioxidant power, and lipid peroxidation assays [12, 13, 32, 45].

Previous reports showed that many wound healing herbs are rich in phenolic and flavonoid contents which play important roles in wound healing activity $[4,25,36]$. These compound effects on the wound healing process might be due to antioxidant, anti-inflammation, antimicrobial, angiogenesis, and cell proliferation stimulation activity [25, 46]. In this study, our results showed that CCLE contains phenolic and flavonoid compounds. Previous studies also indicated that phenolic and flavonoid compounds are present in C. crepidioides leaves [13, 45, 47, 48]. Adedayo et al. (2015) found that $\mathrm{HCl}$-methanolic extract of $\mathrm{C}$. crepidioides leaves contains many compounds belong to phenolic and flavonoid class, including gallic acid, catechin, chlorogenic acid, caffeic acid, ellagic acid, rutin, and quercetin [45]. Among these compounds, gallic acid, chlorogenic acid, ellagic acid, and rutin have been demonstrated to have wound healing activity $[36,49-52]$. These compounds might be relative to wound healing activity of $C$. crepidioides leaves. 


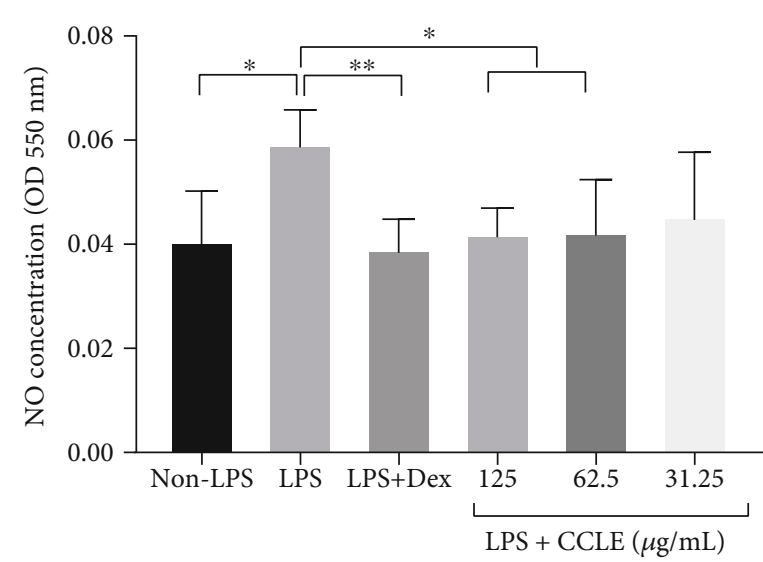

(a)

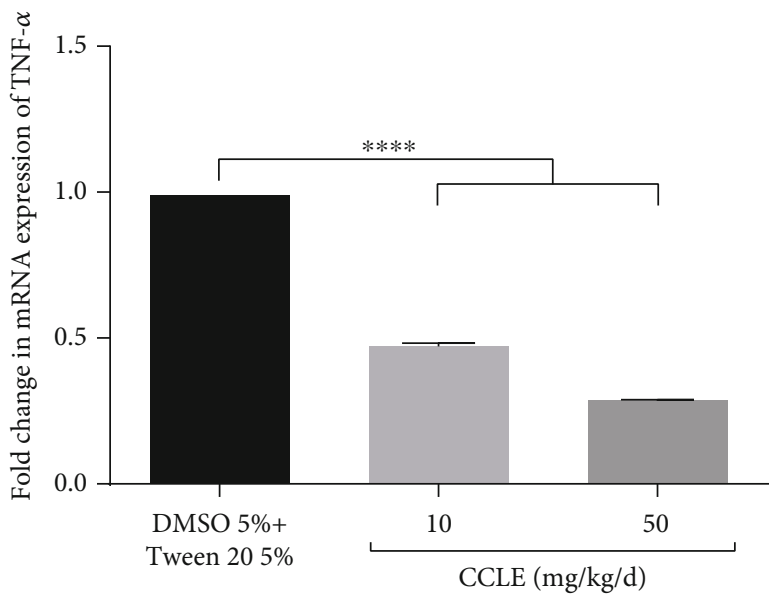

(c)

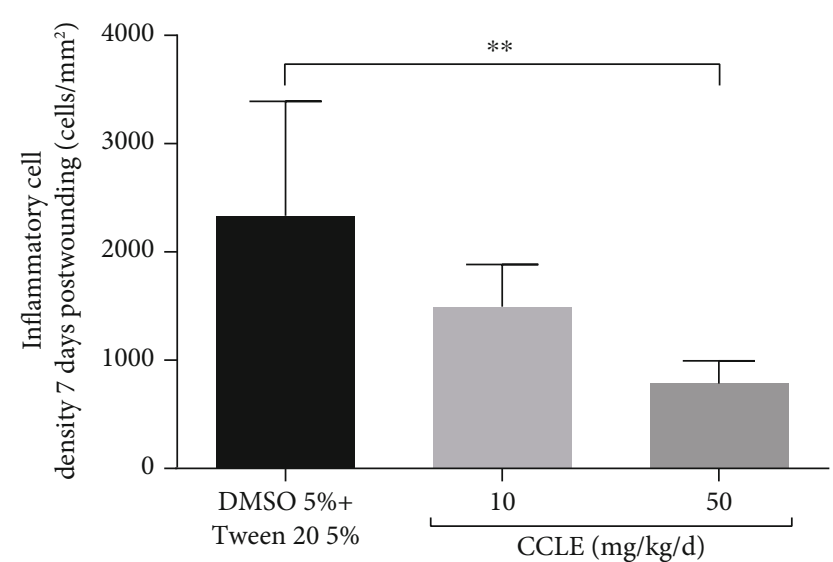

(b)

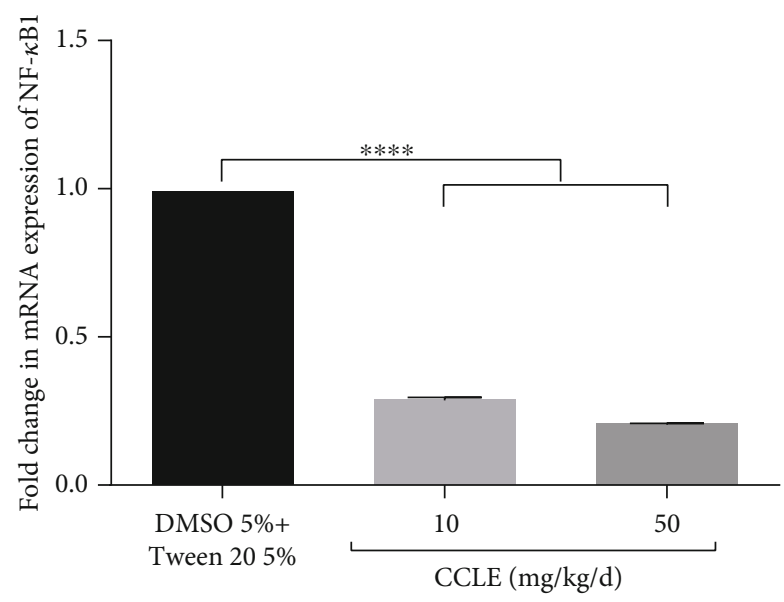

(d)

FIGURE 4: Anti-inflammatory effect of CCLE: (a) NO production inhibition of CCLE in LPS-induced RAW 264.7 cells; LSP was used at a dose of $1 \mu \mathrm{g} / \mathrm{mL}$; (b) inflammatory cell density; (c, d) the mRNA expression level of TNF- $\alpha$ and NF- $\kappa$ B1. Vertical columns and bars showed data as the mean $\pm \mathrm{SD}$; ${ }^{*}$ statistical difference with $p<0.05 ;{ }^{* *} p<0.01 ;{ }^{* * * *} p<0.0001$, compared to vehicle by the ANOVA test.

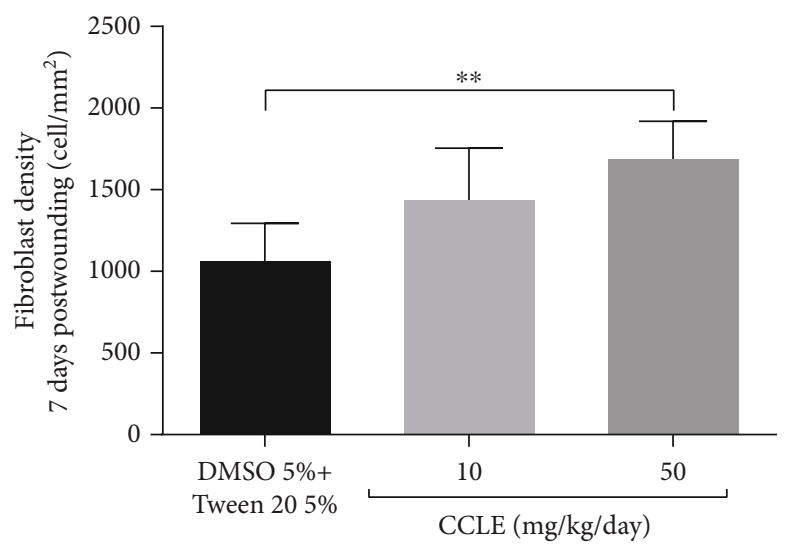

(a)

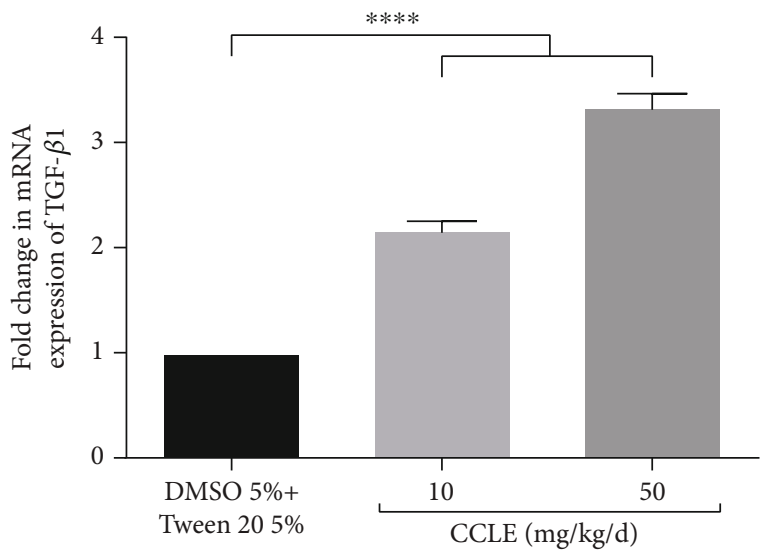

(b)

FIGURE 5: CCLE treatment increased fibroblast density and TGF- $\beta 1$ mRNA expression level in granulation tissue at 7 days postwounding: (a) fibroblast density; (b) TGF- $\beta 1$ mRNA expression level. Vertical columns and bars show data as the mean \pm SD; ${ }^{* *}$ statistical difference with $p<0.01,{ }^{* * * *} p<0,0001$, compared to vehicle by the ANOVA test. 


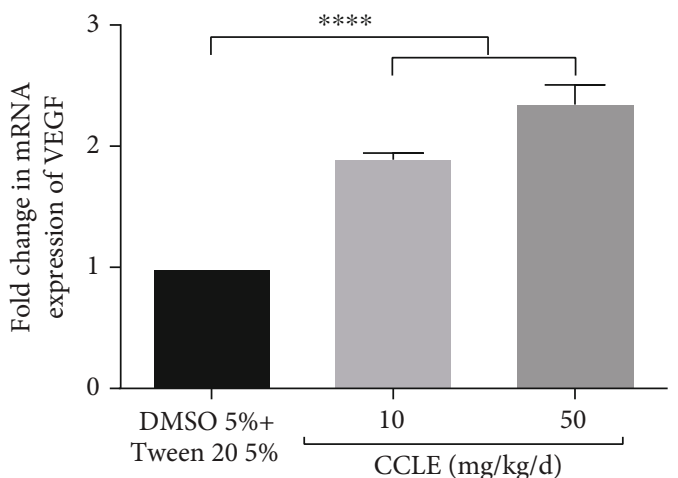

Figure 6: CCLE enhanced the mRNA expression level of VEGF in granulation tissue at 7 days postwounding. Vertical columns and bars show data as the mean $\pm \mathrm{SD}$; ${ }^{* * *}$ statistical difference with $p<$ 0.001 , compared to vehicle by the ANOVA test.

Taken together, this study demonstrated a novel aspect of C. crepidioides on wound healing. Our data revealed that $C$. crepidioides has wound healing activity. The herb's wound healing effects might support its capacities of antioxidant, anti-inflammation, fibroblast proliferation, and angiogenesis.

\section{Abbreviations}

CT: Threshold cycle

CCLE: Crassocephalum crepidioides leaf hydroethanolic extract

DMSO: Dimethyl sulfoxide

DPPH: 2,2-Diphenyl-1-picrylhydrazyl

FBS: $\quad$ Fetal bovine serum

GAPDH: Glyceraldehyde 3-phosphate dehydrogenase

LPS: Lipopolysaccharide

MTT: 3-(4,5-Dimethylthiazol-2-yl)-2,5-diphenyltetrazolium bromide

NF- $\kappa \mathrm{B} 1$ : Nuclear factor kappa-light-chain-enhancer of activated B cells 1

OD: $\quad$ Optical density

TGF- $\beta 1$ : Transforming growth factor 1

TNF- $\alpha$ : Tumor necrosis factor $\alpha$

VEGF: Vascular endothelial growth factor.

\section{Data Availability}

The authors state that all data are available.

\section{Conflicts of Interest}

The authors have no conflicts of interest.

\section{Acknowledgments}

We thank Ph.D. Nguyen Xuan Minh Ai for great contributions to this study. This research is funded by Viet Nam National University Ho Chi Minh City (VNU-HCM) grant number: 562-2018-18-05 and partially supported by Grants-in-Aid from the JSPS Core-to-Core program, B.
Asia-Africa Science Platforms, and sample collection was supported by the Bidoup Nui Ba National Park, Vietnam.

\section{References}

[1] T. Maver, U. Maver, K. S. Kleinschek, D. M. Smrke, and S. Kreft, "A review of herbal medicines in wound healing," International Journal of Dermatology, vol. 54, no. 7, pp. 740751,2015

[2] K. H. Joyce and M. H. Basil, "The principles of wound healing," Expert Review of Dermatology, vol. 8, no. 6, pp. 639658, 2013.

[3] R. L. Thangapazham, S. Sharad, and R. K. Maheshwari, "Phytochemicals in wound healing," Advances in Wound Care, vol. 5, no. 5, pp. 230-241, 2016.

[4] P. K. Ghosh and A. Gaba, "Phyto-extracts in wound healing," Journal of Pharmacy \& Pharmaceutical Sciences, vol. 16, no. 5, pp. 760-820, 2013.

[5] R. Lemmens and N. Bunyapraphatsara, Plant Resources of South-East Asia: Medicinal and Poisonous Plants, Backhuys Publishers, Leiden, 2003.

[6] I. Owokotomo, O. Ekundayo, I. Oladosu, and S. Aboaba, "Analysis of the essential oils of leaves and stems of Crassocephalum crepidioides growing in south western Nigeria," International Journal of Chemistry, vol. 4, no. 2, 2012.

[7] G. Grubben and O. A. Denton, Plant Resources of Tropical Africa 2: Vegetables, Backhuys Publishers, Netherlands, 2004.

[8] A. Adetutu, W. A. Morgan, and O. Corcoran, "Ethnopharmacological survey and in vitro evaluation of wound-healing plants used in South-Western Nigeria," Journal of Ethnopharmacology, vol. 137, no. 1, pp. 50-56, 2011.

[9] D. T. Loi, Glossary of Vietnamese Medicinal Plants, Medical Publishing House, Ha Noi, Vietnam, 2004.

[10] I. A. Owokotomo and E. P. Owokotomo, "Anti-bacterial and brine shrimps lethality studies of the essential oils of Crassocephalum crepidioides (Benth S. More) grown in south west Nigeria," African Journal of Pure and Applied Chemistry, vol. 12, no. 1, pp. 1-7, 2018.

[11] Y. Aniya, T. Koyama, C. Miyagi et al., "Free radical scavenging and hepatoprotective actions of the medicinal herb, Crassocephalum crepidioides from the Okinawa Islands," Biological \& Pharmaceutical Bulletin, vol. 28, no. 1, pp. 19-23, 2005.

[12] B. C. Adedayo, S. I. Oyeleye, I. I. Ejakpovi, and G. Oboh, "Effects of hot water treatment on the radicals scavenging, lipid peroxidation, and $\alpha$-amylase and $\alpha$-glucosidase inhibitory abilities of Crassocephalum crepidioides leaves," Nutrafoods, vol. 14, no. 4, pp. 217-225, 2015.

[13] B. A. Akinpelu, A. Godwin, T. Gbadegesin et al., "Comparative studies on anti-inflammatory, antioxidant and antimutagenic activities of Crassocephalum crepidioides (Bent) leaf cold and hot water extracts," Asian Food Science Journal, vol. 9, no. 1, pp. 1-12, 2019.

[14] K. Tomimori, S. Nakama, R. Kimura, K. Tamaki, C. Ishikawa, and N. Mori, "Antitumor activity and macrophage nitric oxide producing action of medicinal herb, Crassocephalum crepidioides," BMC Complementary and Alternative Medicine, vol. 12, no. 1, 2012.

[15] E. Bahar, K.-M. Akter, G.-H. Lee et al., " $\beta$-Cell protection and antidiabetic activities of Crassocephalum crepidioides (Asteraceae) Benth. S. Moore extract against alloxan-induced oxidative stress via regulation of apoptosis and reactive oxygen 
species (ROS)," BMC Complementary Medicine and Therapies, vol. 17, no. 1, 2017.

[16] S. A. Adefegha, G. Oboh, O. R. Molehin, J. A. Saliu, M. L. Athayde, and A. A. Boligon, "Chromatographic fingerprint analysis, acetylcholinesterase inhibitory properties and antioxidant activities of redflower ragleaf (Crassocephalum Crepidioides) extract," Journal of Food Biochemistry, vol. 40, no. 1, pp. 109-119, 2016.

[17] S. Karmakar, D. Goyary, D. K. Jha, J. Islam, P. Chattopadhya, and P. Raju, "Anti-inflammatory, immunomodulatory and antigenotoxic potential of Crassocephalum crepidioides (Benth.) S. Moore methanolic extract," EC Pharmacology and Toxicology, vol. 6, no. 4, pp. 296-315, 2018.

[18] S. Y. Asadi, P. Parsaei, M. Karimi et al., "Effect of green tea (Camellia sinensis) extract on healing process of surgical wounds in rat," International Journal of Surgery, vol. 11, no. 4, pp. 332-337, 2013.

[19] S. Yakaew, K. Itsarasook, J. Ngoenkam, A. Jessadayannamaetha, J. Viyoch, and M. Ungsurungsie, "Ethanol extract of Terminalia chebula fruit protects against UVB-induced skin damage," Pharmaceutical Biology, vol. 54, no. 11, pp. 2701-2707, 2016.

[20] Q. D. Do, A. E. Angkawijaya, P. L. Tran-Nguyen et al., "Effect of extraction solvent on total phenol content, total flavonoid content, and antioxidant activity of Limnophila aromatica," Journal of Food and Drug Analysis, vol. 22, no. 3, pp. 296302, 2014.

[21] K. Msaada, N. Salem, O. Bachrouch et al., "Chemical composition and antioxidant and antimicrobial activities of wormwood (Artemisia absinthium L.) essential oils and phenolics," Journal of Chemistry, vol. 2015, Article ID 804658, 12 pages, 2015.

[22] S.-J. Heo, W.-J. Yoon, K.-N. Kim et al., "Evaluation of antiinflammatory effect of fucoxanthin isolated from brown algae in lipopolysaccharide-stimulated RAW 264.7 macrophages," Food and Chemical Toxicology, vol. 48, no. 8-9, pp. 20452051, 2010.

[23] G. Manoj and K. Murugan, "Wound healing activity of methanolic and aqueous extracts of Plagiochila beddomei Steph. thallus in rat model," Indian Journal of Experimental Biology, vol. 50, no. 8, pp. 551-558, 2012.

[24] A. A. Ahanger, M. D. Leo, A. Gopal, V. Kant, S. K. Tandan, and D. Kumar, "Pro-healing effects of bilirubin in open excision wound model in rats," International Wound Journal, vol. 13, no. 3, pp. 398-402, 2016.

[25] A. Budovsky, L. Yarmolinsky, and S. Ben-Shabat, "Effect of medicinal plants on wound healing," Wound Repair and Regeneration, vol. 23, no. 2, pp. 171-183, 2015.

[26] J. Cho, M. Kang, and K. Lee, “TGF- $\beta 1$-treated ADSCs-CM promotes expression of type I collagen and MMP-1, migration of human skin fibroblasts, and wound healing in vitro and in vivo," International Journal of Molecular Medicine, vol. 26, no. 6, pp. 901-906, 2010.

[27] P. Bainbridge, "Wound healing and the role of fibroblasts," Journal of Wound Care, vol. 22, no. 8, pp. 407-412, 2013.

[28] M. T. Goldberg, Y. P. Han, C. Yan, M. C. Shaw, and W. L. Garner, "TNF-alpha suppresses alpha-smooth muscle actin expression in human dermal fibroblasts: an implication for abnormal wound healing," The Journal of Investigative Dermatology, vol. 127, no. 11, pp. 2645-2655, 2007.

[29] Y. Gao, W. Jiang, C. Dong et al., "Anti-inflammatory effects of sophocarpine in LPS-induced RAW 264.7 cells via NF- $\kappa$ B and
MAPKs signaling pathways," Toxicology In Vitro, vol. 26, no. 1, pp. 1-6, 2012.

[30] H. Sinno and S. Prakash, "Complements and the wound healing cascade: an updated review," Plastic Surgery International, vol. 2013, Article ID 146764, 7 pages, 2013.

[31] A. D. Kandhare, J. Alam, M. V. K. Patil, A. Sinha, and S. L. Bodhankar, "Wound healing potential of naringin ointment formulation via regulating the expression of inflammatory, apoptotic and growth mediators in experimental rats," Pharmaceutical Biology, vol. 54, no. 3, pp. 419-432, 2016.

[32] M. Bello Oluwasesan, B. O. Abiodun, and A. U. Uduma, “Antioxidant and lipoxygenase inhibitory activity of Crassocephalum crepidioides (Benth.) S. Moore; an underutilized vegetable from Nigeria," FRsCS, vol. 1, no. 2, pp. 28-31, 2019.

[33] S. A. Hashemi, S. A. Madani, and S. Abediankenari, "The review on properties of aloe vera in healing of cutaneous wounds," BioMed Research International, vol. 2015, Article ID 714216, 6 pages, 2015.

[34] Y. Liu, Y. Li, N. Li et al., "TGF- $\beta 1$ promotes scar fibroblasts proliferation and transdifferentiation via up-regulating MicroRNA-21," Scientific Reports, vol. 6, no. 1, article 32231, 2016.

[35] G. F. Pierce, J. E. Tarpley, D. Yanagihara, T. A. Mustoe, G. M. Fox, and A. Thomason, "Platelet-derived growth factor (BB homodimer), transforming growth factor-beta 1, and basic fibroblast growth factor in dermal wound healing. Neovessel and matrix formation and cessation of repair," The American Journal of Pathology, vol. 140, no. 6, pp. 1375-1388, 1992.

[36] A. Gopalakrishnan, M. Ram, S. Kumawat, S. Tandan, and D. Kumar, "Quercetin accelerated cutaneous wound healing in rats by increasing levels of VEGF and TGF- $\beta 1$," Indian Journal of Experimental Biology, vol. 54, no. 3, pp. 187-195, 2016.

[37] M. E. Okur, Ş. Ayla, D. Çiçek Polat, M. Y. Günal, A. Yoltaş, and Ö. Biçeroğlu, "Novel insight into wound healing properties of methanol extract of Capparis ovata Desf. var. palaestina Zohary fruits," The Journal of Pharmacy and Pharmacology, vol. 70, no. 10, pp. 1401-1413, 2018.

[38] I. A. Darby, B. Laverdet, F. Bonté, and A. Desmoulière, "Fibroblasts and myofibroblasts in wound healing," Clinical, Cosmetic and Investigational Dermatology, vol. 7, pp. 301-311, 2014.

[39] K. E. Johnson and T. A. Wilgus, "Vascular endothelial growth factor and angiogenesis in the regulation of cutaneous wound repair," Advances in Wound Care, vol. 3, no. 10, pp. 647-661, 2014.

[40] L. A. DiPietro, "Angiogenesis and wound repair: when enough is enough," Journal of Leukocyte Biology, vol. 100, no. 5, pp. 979-984, 2016.

[41] S. D. Fitzmaurice, R. K. Sivamani, and R. R. Isseroff, "Antioxidant therapies for wound healing: a clinical guide to currently commercially available products," Skin Pharmacology and Physiology, vol. 24, no. 3, pp. 113-126, 2011.

[42] I. Süntar, E. K. Akkol, L. Nahar, and S. D. Sarker, "Wound healing and antioxidant properties: do they coexist in plants?," Free Radicals and Antioxidants, vol. 2, no. 2, pp. 1-7, 2012.

[43] C. Agyare, A. S. Dwobeng, N. Agyepong et al., "Antimicrobial, antioxidant, and wound healing properties of Kigelia africana (Lam.) Beneth. and Strophanthus hispidus DC," Advances in Pharmacological Sciences, vol. 2013, Article ID 692613, 10 pages, 2013.

[44] K. Ilango and V. Chitra, "Wound healing and anti-oxidant activities of the fruit pulp of Limonia acidissima Linn 
(Rutaceae) in rats," Tropical Journal of Pharmaceutical Research, vol. 9, no. 3, 2010.

[45] B. C. Adedayo, G. Oboh, S. I. Oyeleye, I. I. Ejakpovi, A. A. Boligon, and M. L. Athayde, "Blanching alters the phenolic constituents and in vitro antioxidant and anticholinesterases properties of fireweed (Crassocephalum crepidioides)," Journal of Taibah University Medical Sciences, vol. 10, no. 4, pp. 419426, 2015.

[46] M. Georgescu, O. Marinas, M. Popa et al., "Natural compounds for wound healing," in Worldwide Wound Healing: Innovation in Natural and Conventional Methods, F. CJVd, Ed., pp. 61-89, Intech, Croatia, 2016.

[47] J. Arawande, K. E. Olalekan, and B. I. Ayodeji, "Nutritional and phytochemical compositions of fireweed (Crassocephalum crepidioides)," Journal of Agricultural Technology, vol. 9, no. 2, pp. 439-449, 2013.

[48] A. Adjatin, A. Dansi, M. Badoussi et al., "Phytochemical screening and toxicity studies of Crassocephalum rubens (Juss. ex Jacq.) S. Moore and Crassocephalum crepidioides (Benth.) S. Moore consumed as vegetable in Benin," Journal of Chemical and Pharmaceutical Research, vol. 2, pp. 1-13, 2013.

[49] D. Yang, S. Moh, D. Son et al., "Gallic acid promotes wound healing in normal and hyperglucidic conditions," Molecules, vol. 21, no. 7, 2016.

[50] H. S. Song, T. W. Park, U. D. Sohn et al., "The effect of caffeic acid on wound healing in skin-incised mice," The Korean Journal of Physiology and Pharmacology, vol. 12, no. 6, pp. 343347, 2008.

[51] P. Hardany and Y. Wiwik Misaco, "Bambang Sektiari L. Ellagic acid activity in healing process of incision wound on male albino rats (Rattus norvegicus)," KnE Life Sciences, vol. 3, no. 6, pp. 224-233, 2017.

[52] J. S. Almeida, D. M. Benvegnú, N. Boufleur et al., "Hydrogels containing rutin intended for cutaneous administration: efficacy in wound healing in rats," Drug Development and Industrial Pharmacy, vol. 38, no. 7, pp. 792-799, 2012. 